ment. Adult males are easily distinguished from the hens and it is therefore possible to have an open hunting season for males only. This allows liberal hunting by sportsmen without affecting the breeding potential for the following spring. Removal of the excess males benefits the pheasant population. Unlike our Sharp-tailed Grouse, the Pheasant has not adapted himself to our winters and has not much ability in finding protection during winter storms. During such storms drifting snow freezes in his nostrils and feathers, causing death.

\section{COYOTE}

The coyote may well be called the wanderer of the plains. It is well known to most persons and is distributed throughout the settled and fringe areas of the province. The coyote adapts itself readily and lives on both the open plains and the heavily forested areas of the province. A coyote digs its den in some secluded spot where three to eleven young are born. Food is carried to the young until they are able to forage for themselves. The coyote is not a fussy eater and its food consists of small mammals, birds, fruits and even insects. The coyote is also a carrion feeder and farmers sometimes lose poultry and sheep.

Note: I would be very pleased to hear from any reader who found this material of interest. It is certainly possible to do a series on this type of material and if there are any species that you wish to have included please write, care of Dr. G. Ledingham, The Blue Jay Editor.

\title{
Big Game News
}

\section{By W. ARTHUR BENSON}

Deer in the mixed wood forests of Central Saskatchewan are, this winter, in dire straits. This condition has primarily been brought about by two factors: (1) The very deep, fluffy snow which has not been seen so generally for about 25 years, and, (2) the very large deer population which was made even larger by virtue of an inclement hunting season which did not harvest sufficient deer. In this northern, fringe-ofsettlement area, permits were made available to Conservation Officers which allowed deer to be taken in over-populated areas. So far hunters have not been able to find access to these areas and few permits have been issued. In addition, the Department of Natural Resources has provided transportation for feed bought or given by farmers, Fish and Game Leagues and other interested parties. The feed has been taken to areas where deer are in goodly numbers and are in danger of starvation. So far several deer have died and, depending on the weather, many more might die of starvation. When starvation is the cause of death, it is fairly easy to determine by examining the bone marrow, which, intead of being creamy white (healthy), is varying shades of pink and red (starvation). This red condition of the marrow occurs as stored body fat in the marrow is used up, leaving only the red blood cells which are produced in the bones.

If the condition of large deer populations in process of starvation occurred in the Lake States or parts of Ontario and Manitoba, sound wildlife management would dictate that no feeding be done and the deer population be drastically reduced. This is because winters there are permanently bad as far as heavy snow is concerned. It is the heavy snow which troubles the deer by reducing their travelling ability. In the Eastern States, deer "yard up" every year, and the peculiar thing about it is that the same "yards" are used every year and no amount of inducement will make the deer move. In Saskatchewan, our winter conditions normally are less severe as far as snow is concerned and for this reason higher deer populations can be allowed without fear of starvation. Once in 30 years or so, we have a situation like this winter in the mixed-wood area of northern Saskatchewan. If we get a series of winters such as this one, we will have to reduce our deer population or the slow killers of starvation and disease will do it for us. We are fortunate in that our southern area and aspen parkland area are seldom critical. This year deer in the south 
are in no danger except in about three widely scattered particular areas. In the rest of the country, they manage nicely-even easily in some areas, where kind farmers do not mind the deer getting "easy pickings" from haystacks.

\section{CARIBOU}

Two of the most important steps in barren ground caribou management occurred this year in Saskatchewan. The first was a meeting held in Saskatoon in the fall of 1955 comprised of game administrators and research personnel from all government agencies concerned with caribou. At this meeting a Senior Caribou Committee was recommended which would judge research findings and take appropriate unified action. In addition, a Technical Caribou Committee was appointed, which was to unify research, gather facts and provide them to the Senior Caribou Committee.

The second step was the first fall meeting of the Technical Caribou Committee in Prince Albert on January 26 th, 1956. At this meeting technicians and field men from Northwest Territories, Indian Affairs, Canadian Wildlife Service, Alberta Game Branch, Manitoba Gam e Branch, Ontario Department of Lands and Forests and Saskatchewan Game Branch were represented. The meeting was much enhanced by the presence of Dr. Doug Clarke, (Ontario representative) who has the advantage of years of experience and a background of very able work conducted in the Northwest Territories. At the conference, plans were laid to conduct an aerial survey of caribou presently in Saskatchewan. This survey will give needed data on sex and age ratios, range conditions and herd distribution. The survey will be on a co-operative basis and participants will be John Kelsall (Canadian Wildlife Service) and T. A. Harper and R. A. Ruttan (Saskatchewan Game Branch, Biological Division). All three are extremely capable men and also tough enough to withstand the very rigourous climate and ground conditions. Other problems discussed at the meeting were: range studies, wolf control assessment and improvement, means of obtaining accurate native kill figures, standardization of methods of collecting data, improvement of aerial survey techniques and plans for an over-all aerial survey to begin next spring.

The caribou population has dwindled steadily over the past several years until the present when only some 300,000 animals make up the mainland caribou population. Every effort is being made to find the cause of the reduction. Having once found the cause, the effort will then be directed to the correction of the situation. So far, we know that neither predation nor human utilization were the sole factors causing the loss in caribou-though of course they helped. We cannot stop human utilization of caribou unless we wish to starve the humans presently using caribou. We hope that we can eliminate wastage by education and enforcement. It is only by the sincere intergovernment co-operation presently found in the Caribou Committee that we have any hope of collecting and transposing facts into action for caribou management.

\section{RACCOONS IN SASKATCHEWAN}

S. A. Mann reports an unusual occurrence from the Cypress Hills District - four Raccoons taken in the early winter on Bear Creek. Joyce Gunn from Spirit Lake also reports a Raccoon that arrived in their yard January 21, taking refuge in the garage. When she wrote on January 26, the Raccoon was still sheltering in the garage, thriving on a diet of fish, table scraps and bread and milk. The Gunn family settled at Good Spirit Lake in 1887, and this is the first record that they have of a Raccoon in the district.

\section{UNSEASONABLE ACTIVITY OF SKUNK}

Although we do not usually see skunks after the cold weather has set in, Joyce Gunn (Spirit Lake) reports that a family of four has been visiting their yard this winter on the average of once every ten days. The smallest one of the four took a liking to the dog's box and stays behind after the rest of the family leaves to have a "cat-nap" in his box. The dog sits back at a safe distance and waits for it to leave - he has learnt it is much easier to let it come out on its own than go in after it! 